\title{
Management of primary hyperparathyroidism during pregnancy: a case series of the lessons learnt.
}

\author{
K McCullough1; NM Martin1; F Palazzo1; C Williamson²; K Meeran1. \\ ${ }^{1}$ Imperial Centre for Endocrinology, Hammersmith Hospital, Imperial College Healthcare NHS Trust, Du Cane Road, London, W12 0NN. \\ 2Maternal and Fetal Disease Group, Queen Charlotte's Hospital, Imperial College, London, W12 OHS.
}

\section{BACKGROUND}

Primary hyperparathyroidism (PHPT) is a common condition, affecting approximately $1 \%$ of the general population. In women of childbearing age, the correct diagnosis and management is particularly important since PHPT is associated with miscarriage, pre-eclampsia, intrauterine growth restriction, preterm delivery and postpartum neonatal hypocalcaemia. We describe a case series of six women diagnosed with PHPT and their management during pregnancy. We discuss the various diagnostic challenges including interpretation of urine calcium to creatinine clearance ratio during pregnancy, the importance of vitamin $\mathrm{D}$ replacement during diagnostic work up and the pros and cons of performing surgery during the $2^{\text {nd }}$ trimester of pregnancy.

\section{RESULTS}

\begin{tabular}{|c|c|c|c|c|c|c|c|c|}
\hline Case & $\begin{array}{l}\text { Gestation at } \\
\text { presentation }\end{array}$ & $\begin{array}{l}\text { Presenting Ca2+ } \\
(\mathrm{mmol} / \mathrm{l})\end{array}$ & $\begin{array}{l}\text { Urine collection } \\
\text { data }\end{array}$ & $\begin{array}{l}\text { Symptoms/ } \\
\text { complications }\end{array}$ & Diagnosis & $\begin{array}{l}\text { Adenoma size }(\mathrm{mm}) \\
\text { and weight }(\mathrm{g})\end{array}$ & Management & Outcome \\
\hline 1 & $34 / 40$ & 2.9 & $\begin{array}{c}\text { UCCR } 0.015 \\
\text { (CaSR mutation - } \\
\text { ve) }\end{array}$ & Nil & $\begin{array}{l}4 \text { gland } \\
\text { hyperplasia }\end{array}$ & N/A & Conservative & $\begin{array}{l}\text { Declined surgery, asymptomatic. Post-partum Ca2+ } 2.52 \mathrm{mmol} / / \text {, vit D } 70 \\
\text { nmol//, PTH } 15.7 \text { pmol/I. Rpt USS normal. Re-referred to local endocrinology } \\
\text { team. }\end{array}$ \\
\hline 2 & $4 / 40$ & 2.79 & $\begin{array}{l}24 \mathrm{hr} \text { urine } \mathrm{Ca} 2+: \\
\quad 4.6 \mathrm{mmol} / \mathrm{l}\end{array}$ & Hypertension & $\begin{array}{l}\text { Parathyroid } \\
\text { adenoma }\end{array}$ & $12 \mathrm{~mm} ; 0.61 \mathrm{~g}$ & $\begin{array}{l}\text { Parathyroidectomy } \\
19 / 40\end{array}$ & Normocalcaemic. Normal delivery. MEN negative. \\
\hline 3 & Pre-conception & 2.67 & $\begin{array}{c}24 \mathrm{hr} \text { urine } \mathrm{Ca} 2+: \\
2.99 \mathrm{mmol} / \mathrm{l}\end{array}$ & Nil & $\begin{array}{l}\text { Parathyroid } \\
\text { adenoma }\end{array}$ & $32 \mathrm{~mm} ; 4.8 \mathrm{~g}$ & $\begin{array}{l}\text { Parathyroidectomy } \\
19 / 40\end{array}$ & $\begin{array}{l}\text { Normocalcaemic post op. Normal delivery. Recurrence of } \\
\text { hyperparathyroidism with ?new adenoma on localisation studies. Declined } \\
\text { further surgery, asymptomatic.Referred back to local endocrinologist. Latest } \\
\text { bloods ( } 2 \text { years post op) show normocalcaemia. }\end{array}$ \\
\hline 4 & Pre-conception & 2.78 & N/A & $\begin{array}{l}\text { Recurrent miscarriages } \\
\text { x3 (1st trimester); } \\
\text { bone pain }\end{array}$ & $\begin{array}{l}\text { Parathyroid } \\
\text { adenoma }\end{array}$ & $40 \mathrm{~mm} ; 1.42 \mathrm{~g}$ & $\begin{array}{l}\text { Parathyroidectomy } \\
\text { following } \\
\text { miscarriage }\end{array}$ & $\begin{array}{l}\text { Miscarriage during first trimester whilst awaiting parathyroidectomy. } \\
\text { Elective surgery } 4 \text { months later. Normocalcaemic, discharged from regular } \\
\text { follow-up. }\end{array}$ \\
\hline 5 & Pre-conception & 2.64 & $\begin{array}{c}\text { UCCR } 0.011 ; \\
0.0138 ; 0.0166\end{array}$ & $\begin{array}{l}\text { Miscarriages (1st } \\
\text { trimester 10/40); bone } \\
\text { pain; osteopenia. }\end{array}$ & $\begin{array}{l}\text { Parathyroid } \\
\text { adenoma }\end{array}$ & $16 \mathrm{~mm} ; 1.35 \mathrm{~g}$ & $\begin{array}{l}\text { Parathyroidectomy } \\
18 / 40\end{array}$ & $\begin{array}{l}\text { Normocalcaemic. C-section delivery due to pre-labour membrane rupture } \\
\text { and infection. MEN negative. }\end{array}$ \\
\hline 6 & $18 / 40$ & 3.08 & UCCR 0.0264 & $\begin{array}{l}\text { Constipation, polyuria, } \\
\text { polydipsia, bone pain. }\end{array}$ & $\begin{array}{l}5 \text { gland } \\
\text { hyperplasia }\end{array}$ & N/A & $\begin{array}{l}4.5 \\
\text { parathyroidectomy } \\
20 / 40\end{array}$ & $\begin{array}{l}\text { Normocalcaemic post-op. Pre-eclampsia in 3rd trimester, ventouse } \\
\text { delivery.Neonatal hypercalcaemia }(2.62 \mathrm{mmol} / \mathrm{l}) \text { - resolved. Discharged. }\end{array}$ \\
\hline
\end{tabular}

\section{DISCUSSION}

These cases illustrate the diagnostic challenges faced by the endocrine and obstetric team in managing primary hyperparathyroidism (PHPT) during pregnancy. In four cases, the PHPT was secondary to a parathyroid adenoma whilst in two patients, parathyroid hyperplasia was diagnosed. Four patients underwent parathyroidectomy during the second trimester of pregnancy. One patient was diagnosed during her third trimester and was managed conservatively. In three women, hypercalcaemia was detected prior to conception and in one case this was associated with a further miscarriage during the first trimester. This highlights the importance of prompt diagnosis and if PHPT confirmed, appropriate counselling about maternal and fetal risks and the need to expedite surgery. Although case reports describe surgical intervention at different stages during pregnancy, it is generally accepted that the $2^{\text {nd }}$ trimester is the safest time to operate during pregnancy (1). However, this apparent delay for definitive treatment does expose the mother and foetus to high circulating levels of calcium and increased risk of miscarriage. Furthermore, sestamibi scanning for parathyroid localisation is contraindicated in pregnancy, limiting the opportunity for minimally invasive parathyroidectomy and therefore surgery under local anaesthesia.

Case 5 demonstrates the difficulties in interpreting urine calcium to creatinine ratios (UCCRs) during pregnancy and the differentiation between familial hypocalciuric hypercalcaemia (FHH) and PHPT. FHH should be excluded to avoid an unnecessary parathyroidectomy. Furthermore, during diagnostic work-up, it is important to ensure that patients are vitamin D replete, since low vitamin D reduces urine calcium excretion (2).

During pregnancy, maternal PTH secretion is increased in order to maintain serum ionic calcium levels in the face of expanding extracellular fluid volume, increased urinary excretion and calcium transfer to the growing foetus. Maternal creatinine clearance increases by around $25 \%$ during pregnancy (3). A previous study has shown a significant correlation between calcium excretion and creatinine clearance, thought to be due to an increase in glomerular filtration rate $(4,5)$. Although current literature suggests that a UCCR of $>0.01$ excludes FHH $(6,7,8)$, studies have shown the UCCR can vary significantly in FHH and PHPT. For example, the UCCR ranges from 0.002-0.026 in patients with FHH (9) and 0.0028-0.0624 in patients with PHPT (10). As such, a UCCR cut-off value of 0.02 has been advocated to differentiate between FHH and PHPT, followed by CaSR gene analysis in those with a low UCCR $(11,12)$. Importantly, published literature on interpretation of UCCRs to date does not include pregnant women and correct interpretation of the UCCR during pregnancy is unknown.

\section{CONCLUSION}

These cases illustrate the difficulties faced in diagnosing and managing women with PHPT during pregnancy, who require close monitoring and definitive management of PHPT. In particular, prompt diagnosis is required and if PHPT confirmed, appropriate counselling should be undertaken about maternal and fetal risks and the need to expedite surgery. In three cases, hypercalcaemia was detected prior to conception and was associated with a history of miscarriages in two of these cases. This highlights the need for counselling and definitive treatment prior to conception.

\section{REFERENCES}

(1) Norm

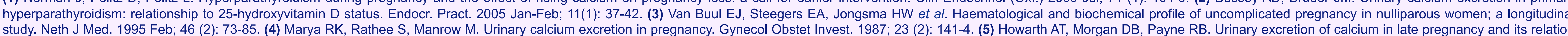
to creatinine clearance. Am J Obstet Gynecol. 1977 Nov 1; 129 (5): 499-502. (6) Bilezikian JP, Potts JT Jr, Fuleihan Gel-H, et al. Summary statement from a workshop on asymptomatic primary hyperparathyroidism: a perspective for the 21st century. J Clin Endocrinol
Metab 2002; $87: 5353-61$. (7) Glendenning P. Diagnosis of primary hyperparathyroidism: controversies, practical issues and the need for Australian guidelines. Intern Med J 2003;33:598 - 603. (8) Gunn IR, Gaffney D. Clinical and laboratory features of calcium-sensing Metab 2002;87:5353-61. (7) Glendenning P. Diagnosis of primary hyperparathyroidism: controversies, practical issues and the need for Australian guidelines. Intern Med J 2003;33:598 - 603. (8) Gunn IR, Gaffney D. Clinical and laboratory features of calcium-sensing
receptor disorders: a systematic review. Ann Clin Biochem 2004;41:441-58. (9) Christensen SE, Nissen PH, Vestergaard P et al, Plasma 25-hydroxyvitamin D, 1,25-dihydroxyvitamin D, and parathyroid hormone in familial hypocalciuric hypercalcemia and primary

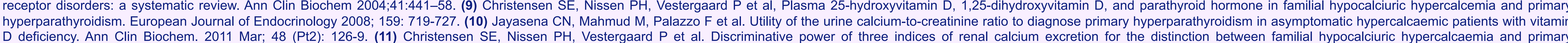
hyperparathyroidism: a follow-up study on methods. Clin Endocrinol 2008; Nov; 69 (5): 713-20. (12) Christensen SE, Nissen PH, Vestergaard P, Mosekilde L. Familial hypocalciuric hypercalcaemia: a review. Curr Opin Endocrinol Diabetes Obes. 2011 Dec; 18 (6): 